\title{
Prawa i wolności obywatelskie w warunkach epidemii Covid-19
}

\author{
Civil rights and liberties in conditions of the Covid-19 epidemic
}

\section{Streszczenie:}

Podjęcie tematu praw i wolności obywatelskich w warunkach epidemii Covid-19 w dużej mierze podyktowane zostało potrzebą zweryfikowania pojawiających się w przestrzeni publicznej opinii, jakoby rząd polski w tych trudnych czasach poprzez działania prawodawcze godził w podstawowe swobody obywatelskie. Reakcją większości rządzących na świecie wobec rozprzestrzenianie się wirusa SARS-CoV-2 było wprowadzanie odpowiednich regulacji prawnych, mających na celu ograniczenie lub zahamowanie epidemii i władze polskie nie stanowiły tu wyjątku. Niniejsze opracowanie w dużej mierze koncentruje się na omówieniu konkretnych działań prawnych podjętych przez rząd premiera Mateusza Morawieckiego w czasie epidemii, które w opinii wielu ekspertów mogły godzić w prawa i wolności obywatelskie. W artykule zaprezentowane są również przykłady regulacji prawnych wprowadzanych przez polski rząd, które nosiły znamiona wadliwej i niepoprawnej legislacji, co w konsekwencji mogło podważać zasadę demokratycznego państwa prawa. Zauważalne próby zahamowania epidemii COVID-19 wymagały przedsięwzięcia określonych działań prawnych. Poważne wątpliwości budzi jednak sposób ich wprowadzania, zgodność z zasadami stanowienia prawa, a co ważniejsze - godzenie w określone swobody obywatelskie.

Słowa kluczowe: koronawirus, COVID-19, prawa i wolności obywatelskie, prawa człowieka, prawo

\begin{abstract}
:
Bringing up the subject of civil rights and civil liberties during the Covid-19 epidemic, to a large extent, has been caused by a willingness to verify opinions occurring in public space, which say that the Polish government in these difficult times through legislation was against fundamental civil liberties. The reaction of most governments to the spread of
\end{abstract}


Adam Wąsikowski - Prawa i wolności obywatelskie...

the Sars-CoV-2 virus was to implement appropriate legal regulations aimed at restricting or stopping the epidemic, and Polish authorities were not an exception. The following elaboration will mainly focus on discussing specific legal actions taken by the government of Prime Minister Mateusz Morawiecki during the epidemic, which in the opinion of many experts, violated civil rights and liberties. The article also presents examples of legal regulations implemented by the Polish government, which bore the hallmarks of defective and incorrect legislation, which in consequence could undermine the principle of a democratic state ruled by law. Noticeable attempts of stopping the COVID-19 epidemic through Polish authorities required undertaking particular legal actions. However, the way of implementing these, compatibility with present legislative principles, and the most important - violating fundamental rights and liberties are highly questionable.

Keywords: coronavirus, COVID-19, civil rights and civil liberties, human rights, law

\section{Podziękowania dla prof. Alfreda Lutrzykowskiego}

za udzielenie wsparcia merytorycznego i edytorskiego podczas pisania niniejszej pracy

\section{Wstęp}

Opracowanie niniejsze poświęcone jest fundamentalnemu w państwach demokratycznych problemowi przestrzegania praw i wolności obywatelskich w sytuacji zaistnienia szczególnego zagrożenia, w której niezbędne jest sięganie do szczególnych również środków i wyjątkowych regulacji prawnych oraz rozwiązań organizacyjnych ${ }^{1}$. Rozważania tu zawarte dotyczą głównie działań władz publicznych Rzeczypospolitej Polskiej w czasie pandemii COVID-19², w okresie roku, od marca 2020 r. do chwili obecnej.

Każda sytuacja pojawiająca się w życiu zbiorowym, która nie była dotąd znana lub nie występowała na tyle często i regularnie, by można było wypracować wobec niej konkretne mechanizmy działania bądź reagowania, nosi znamiona sytuacji nietypowej, odbiegającej od znanej dotychczas normy. Pandemię COVID-19, z którą w momencie pisania

$1 \quad$ Zob. L. Garlicki, Polskie prawo konstytucyjne. Zarys wykładu. Warszawa 2019, s. 445.

2 W lutym 2020 r. Światowa Organizacja Zdrowia (WHO) ustanowiła oficjalną nazwę SARS-CoV-2 określającą wirusa wywołującego chorobę COVID-19 (Coronavirus Disease 2019). 
tego tekstu zmaga się większość państw na kuli ziemskiej, niewątpliwie można zaliczyć do tego typu sytuacji. W związku z nią władze niemal wszystkich państw na świecie musiały wdrożyć w życie w wielu przypadkach całkowicie nowe przepisy prawne lub stosować nieznane do tej pory regulacje i rozwiązania organizacyjne, aby zapobiec rozprzestrzenianiu się wirusa oraz rozwojowi pandemii. Jednocześnie nie wolno było zapominać przy tym o właściwej i poprawnej legislacji, a także należało respektować prawa i wolności obywatelskie, z czym nie wszędzie pomyślnie radzono sobie. Choroba wywoływana wirusem SARS-CoV-2 całkowicie zmieniła dotychczasowe życie większości społeczeństw, powodując wiele najrozmaitszych problemów, ograniczeń i zakazów. Różne były w poszczególnych krajach reakcje obywateli, zwłaszcza w początkowej fazie pandemii. Niemal natychmiast w społecznym dyskursie pojawiły się pytania i wątpliwości dotyczące przestrzegania praw i wolności obywatelskich, które jak często podnoszono nie zawsze są respektowane $\mathrm{w}$ tych trudnych czasach. $\mathrm{Z}$ tym wiąże się istotny problem dopuszczalności ograniczenia praw i wolności człowieka i obywatela, określenia warunków (sytuacji), zakresu oraz formy prawnej takich decyzji. Podstawowe zasady dopuszczalnych ograniczeń wskazane zostały w art. 31 ust. 3 Konstytucji RP oraz w innych przepisach dotyczących konkretnych praw i wolności.

\section{Pojęcie „praw i wolności obywatelskich”}

Aby lepiej zrozumieć istotę badanego problemu, należy dokonać skrótowej choćby eksplikacji pojęcia „prawa i wolności obywatelskie”. Jak zauważa M. Chmaj:

\footnotetext{
„Wolności i prawa nie należą do kategorii dających się ująć w proste formuły. Wynika to z wielu przyczyn, wśród których najważniejszymi są: 1) niejednoznaczność pojęć, funkcjonujących zarówno w dyskursie naukowym, normatywnym, jak i potocznym; 2) otwarty charakter, zmieniający się wraz z rozwojem wiedzy o człowieku, rozwojem społecznym, moralnym i kulturowym ludzkości”3.
}

$3 \quad$ M. Chmaj, Wolności i prawa człowieka w Konstytucji Rzeczypospolitej Polskiej, Warszawa 2008, s. 9. 
Adam Wąsikowski - Prawa i wolności obywatelskie...

Zaprezentowane stanowisko wydaje się traktować pojęcie „praw i wolności" w sposób bardzo ogólny, co może powodować pewne trudności jeżeli idzie o ich rozumienie. Dlatego na potrzeby tej pracy będę posiłkować się konkretnymi definicjami i określeniami, które stosowane są, np. w aktach prawnych. Prawa i wolności są w nich zazwyczaj ujmowane jako przyrodzone, niezbywalne prawa jednostki, takie jak: prawo do życia, wolność osobista, własność, równość, bezpieczeństwo. W literaturze, z uwagi na ich zasadniczy charakter, mówi się o swoistym fundamentalizmie praw człowieka ${ }^{4}$. Uogólniając, należy zauważyć, że „wolności i prawa obywatelskie” współcześnie postrzegane są jako uprawnienia i swobody jednostki umożliwiające jej nieskrępowany rozwój na wszystkich płaszczyznach ${ }^{5}$. Na przestrzeni setek lat były one przedmiotem zainteresowania wielu myślicieli. Zmieniał się również sposób ich rozumienia i definiowania.

„Prawa i wolności” nie w każdym momencie dziejów postrzegano w taki sam sposób, zaś działania na ich rzecz były niekiedy przyczynkiem wielu konfliktów. Pod koniec XVIII wieku w niektórych państwach na sile przybrały ruchy, myśli i idee mające na celu ustanowienie pewnych zasad służących zapobieżeniu nadużyciom władzy, które występowały, np. w monarchiach absolutnych. Jako przykład tego typu dążeń można podać dokument programowy rewolucji francuskiej, czyli Deklarację praw człowieka i obywatela, w której zapisano m.in. wolność fizyczną i duchową, prawo własności, równość wobec prawa i sądu'. Zasady te $\mathrm{w}$ większym lub mniejszym stopniu wpływały na kształtowanie się praw i wolności obywatelskich oraz uwzględniania ich w rozwiązaniach ustrojowych. Ujmując tę kwestię w sposób skrótowy, można zauważyć, że pojęcie praw i wolności obywatelskich odgrywało zasadniczą rolę w procesie narodzin koncepcji demokratycznego pań-

A. Michalska, Prawa człowieka w systemie norm międzynarodowych, Warszawa-Poznań 1982, s. 113.

5 S. Stecko, Prawa i wolności człowieka i obywatela w świetle Konstytucji RP, „Przegląd Prawa Konstytucyjnego" 2018, nr 1 (41), s. 180.

$6 \quad$ M. Szczaniecki, K. Sójka-Zielińska, Powszechna historia państwa i prawa, Warszawa 2009, s. 324-325. 
stwa. W tym ujęciu jednostka traktowana jest w sposób podmiotowy oraz przysługują jej pewne przyrodzone prawa i wolności, wywodzone z prawa naturalnego.

\section{Prawa i wolności obywatelskie w świetle Konstytucji Rzeczypospolitej Polskiej}

Zasada praw i wolności obywatelskich znalazła swój znaczący wyraz w Konstytucji Rzeczypospolitej Polskiej z dnia 2 kwietnia 1997 roku. Jej II rozdział nosi następujący tytuł: „Wolności, prawa i obowiązki człowieka i obywatela". Należy w tym miejscu dodać, że odwołania do praw i wolności znajdziemy również w artykułach wykraczających poza II rozdział Konstytucji RP, choć zostały w nich one wyrażone w sposób mniej lub bardziej bezpośredni. W tej części rozważań warto zwrócić uwagę czytelnika na dwa pierwsze człony tytułu rozdziału II Konstytucji RP, czyli na „wolności i prawa obywatelskie”, analizując ich treść w kontekście szczególnej sytuacji spowodowanej rozprzestrzenianiem się choroby COVID-19. W tym miejscu warto zauważyć też, że „prawa” i „wolności” czasami są postrzegane jako synonimy, choć de facto są to dwa odrębne pojęcia. Posiłkując się przykładem, można zauważyć, że art. 54. Konstytucji RP, stanowiący o w o l n o ś c i słowa, może być niekiedy, przez jakąś część obywateli postrzegany jako p r a w o do nieskrępowanego wyrażania i artykułowania swoich myśli, przekonań, poglądów, itp. Opisywanie i wyjaśnianie zjawisk społecznych, w tym fenomenu prawa wymaga dyscypliny i precyzji w operowaniu pojęciami, zwłaszcza pokrewnymi oraz bliskoznacznymi. To bowiem stanowi warunek komunikatywności i prawidłowej interpretacji norm prawnych. Oczywiście nie znaczy to, że ktoś traktujący wolności i prawa jako synonimy popełnił kardynalny błąd, jednak należy pamiętać i zawsze mieć na względzie właściwe rozumienie i interpretowanie konkretnych przepisów. Objaśnianiu i interpretowaniu norm prawnych musi towarzyszyć świadomość, że w tym konkretnym przypadku wolności, jak i prawa obywatelskie należą do bardzo ważnych czynników determinujących zachowania każdej jednostki, ale także poszczególnych grup społecz- 
Adam Wąsikowski - Prawa i wolności obywatelskie...

nych i wreszcie całego społeczeństwa. Siła norm prawnych wyrażająca się zdolnością do kształtowania zachowań jednostkowych i zbiorowych zderza się niejako $\mathrm{z}$ naturalnym dążeniem do podejmowania decyzji zgodnie z własną wolą. Historia dostarcza niezaprzeczalnych dowodów, że wolności i prawa, ujęte zazwyczaj w Konstytucjach, są takimi czynnikami w społeczeństwach i państwach demokratycznych, których instytucje działają na podstawie i w ramach obowiązującego prawa, nawet w sytuacjach nadzwyczajnych. W ustrojach autorytarnych prawo jest stosunkowo prostą implikacją woli monarchy, wodza, dyktatora, junty. W polskiej Konstytucji nie bez powodu został im poświęcony odrębny, obszerny rozdział art. 30-81), co było dobitnym potwierdzeniem przez sprawujące wówczas władzę siły polityczne, że po roku 1989 Rzeczpospolita Polska stała się demokratycznym państwem prawnym, respektującym w pełni wolności i prawa obywatelskie. Warto w tym miejscu dodać, że obywatele oprócz tego, że posiadają wolności i prawa, powinni pamiętać również o obowiązkach wskazanych w tym rozdziale (art. 82-86) Konstytucji. Zresztą sam tytuł tego rozdziału brzmi: „Wolności, prawa i obowiązki człowieka i obywatela”. Troska o dobro wspólne oraz obowiązek przestrzegania prawa Rzeczypospolitej Polskiej wymienione są tu w pierwszej kolejności.

Konstytucja RP z 1997 roku ustanawia stosunkowo bogaty katalog praw i wolności obywatela i człowieka. Liczba wolności, wyrażonych w rozdziale II polskiej ustawy zasadniczej oraz poza nim, wprost lub pośrednio, sięga kilkudziesięciu. Obejmują one m.in. wolności i prawa: osobiste, polityczne, ekonomiczne, socjalne i kulturalne, a także te definiowane jako środki ochrony wolności. Nie budzi wątpliwości przekonanie, że to właśnie prawa i wolności najdobitniej określają status jednostki, „człowieka, każdego, wszystkich”, jak pisze L. Garlicki, chyba że „wyraźnie są adresowane tylko do obywateli”, przy czym „większość (...) praw i wolności nie jest ograniczona wymogiem posiadania obywatelstwa"7. Wyraźnie precyzuje to art. 37 Konstytucji RP stwierdza-

7 L. Garlicki, Polskie prawo konstytucyjne, op. cit., s.113. 
jąc: „1. Kto znajduje się pod władzą Rzeczypospolitej Polskiej, korzysta $\mathrm{z}$ wolności i praw zapewnionych w Konstytucji. 2. Wyjątki od tej zasady, odnoszące się do cudzoziemców, określa ustawa". Warto przy tym nadmienić, że we współczesnym społeczeństwie, w żadnym także demokratycznym państwie trudno wyobrazić sobie istnienie i stosowanie wolności i praw jednostki o charakterze absolutnym, swobód niepodważalnych i niepoddających się jakimkolwiek ograniczeniom. Wynika to $\mathrm{z}$ zasad organizacji i funkcjonowania społeczeństwa jako swoistej wspólnoty. A zatem wolności i prawa mogą być w pewnych sytuacjach ograniczane bądź całkowicie zawieszane. Oczywiście muszą zachodzić określone w przepisach konstytucyjnych przesłanki lub wyrażając się bardziej precyzyjnie, faktyczne stany, wymagające ograniczenia bądź zawieszenia wolności i praw obywatelskich. Współcześnie znaczącą rolę odgrywają również zobowiązania poszczególnych państw wynikające z międzynarodowych traktatów dotyczących praw człowieka. Konstytucja RP (art. 31. ust. 3) dopuszcza możliwość ustanawiania ograniczeń w korzystaniu z ustanowionych w niej praw i wolności w sytuacjach szczególnych, niosących zagrożenie dla wartości najwyższych. Są nimi: bezpieczeństwo państwa, porządek publiczny, środowisko, zdrowie publiczne, moralność publiczna oraz wolności i prawa innych osób. Ograniczenia te mogą być ustanowione jedynie w celu ochrony tych wartości i nie mogą naruszać istoty wolności i praw. Szczególnym przypadkiem sytuacji powodującej ustanowienie ograniczeń praw i wolności jednostki jest wprowadzenie stanu nadzwyczajnego, będącego reakcją na pojawienie się szczególnego zagrożenia, gdy zwykłe środki konstytucyjne stają się niewystarczające. $\mathrm{W}$ takiej sytuacji, zgodnie $\mathrm{z}$ art. 228 ust.1 Konstytucji RP może być wprowadzony: stan wojenny, stan wyjątkowy lub stan klęski żywiołowej.

Kilkusetletnie zdobycze demokratycznego prawodawstwa, jakimi są niewątpliwie prawa i wolności obywatelskie nie mogą być po prostu uchylone ot tak, np. w związku z kaprysem rządzących czy interesem określonych środowisk politycznych. Dlatego sytuacja, w której mogą one zostać ograniczone bądź zawieszone, musi być niebywale istotna, 
Adam Wąsikowski - Prawa i wolności obywatelskie...

rzeczywista, realnie nadzwyczajna. Muszą za tymi rozwiązaniami przemawiać argumenty i okoliczności wiążące się z przedkładaniem ponad nie (prawa i wolności) dobra wyższego, takiego jak zdrowie i życie jednostek bądź całego społeczeństwa. Warto jeszcze zastrzec, że prawa i wolności obywatelskie mogą być ograniczane czy derogowane tylko na pewien czas, w którym ma miejsce sytuacja nadzwyczajna. To bowiem jest nieodłączną zasadą ustrojową współczesnego, demokratycznego państwa prawa. Nie mogą też ograniczenia te w żadnej mierze godzić w istotę praw i wolności, o czym stanowczo mówi ostatnie zdanie art. 31. ust.3 Konstytucji RP.

\section{Regulacja prawne wdrażane w czasie epidemii COVID-19 przez polski rząd}

Jest oczywiste, że nadzwyczajna sytuacja, którą niewątpliwie jest pandemia COVID-19, wymagała i nadal wymaga podejmowania wielu działań, w tym pilnego opracowania i wdrożenia odpowiednich regulacji prawnych ${ }^{8}$. Od rozsądnej władzy, w tak niebezpiecznych czasach, powinniśmy oczekiwać, aby kierowała się przede wszystkim dobrem obywateli oraz troszczyła się o ich zdrowie i życie. Działania polskich władz publicznych, głównie rządu, które mogliśmy obserwować na przestrzeni od marca 2020 roku były podyktowane dążeniem do zahamowania rozprzestrzeniania się choroby Covid-19 a tym samym ratowania zdrowia i życia mieszkańców Polski. Poszczególne organy i przedstawiciele władzy przyjmowali doraźne rozwiązania, takie jak wprowadzenie reżimu sanitarnego, nakazu zasłaniania ust i nosa w przestrzeni publicznej, czy regulacje zakazujące gromadzenia się. Oczywiście nie można było przewidzieć, czy tego typu przedsięwzięcia w konsekwencji okazały lub okażą się trafne i skuteczne. Rozprzestrzenianie się wirusa SARS-CoV-2 na świecie było na tyle nieoczekiwanym zjawiskiem, że podjęte na wszystkich kontynentach działania prawne i logistyczne nie przynosiły natychmiastowego skutku, a więc ograniczenia rozwoju pandemii. Sy-

8 Jak podaje Barometrprawa.pl, tylko do końca czerwca 2020 r. wydano w Polsce 9 ustaw i 188 rozporządzeń dotyczących COVID-19, [dostęp: 21.03.2021 r.] 
tuacja zaistniała w Polsce nie odbiegała od obrazu wydarzeń w innych europejskich państwach.

Obiektywna ocena działania w tym zakresie polskich władz jest zadaniem niezwykle trudnym i odpowiedzialnym. Warto pamiętać, że rządzący znaleźli się w takiej sytuacji po raz pierwszy. Należy więc zakładać, że działali oni, ujmując to najogólniej, dla dobra obywateli. Jednak jak zawsze przy tak radykalnych działaniach organów władzy rodzi się pytanie, czy działały one na podstawie i w granicach prawa, respektując jednocześnie swobody obywatelskie? Wielu prawników i obserwatorów i komentatorów życia społecznego podnosi bowiem, że polski rząd w czasach pandemii m. in. nie przestrzegał przyjętych i obowiązujących w polskim systemie prawnym konstytucyjnych zasad, ustanawiających określony porządek niezbędnych przedsięwzięć prawodawczych ${ }^{9}$. Konstytucja RP w art. 31. ust. 3 wyklucza swobodę i dowolność w tym zakresie, postanawiając, iż ograniczenia $\mathrm{w}$ zakresie korzystania $\mathrm{z}$ konstytucyjnych wolności i praw mogą być ustanawiane tylko w ustawie. Nie budzą również wątpliwości dyspozycje Konstytucji RP dotyczące stanów nadzwyczajnych, które mogą być wprowadzone tylko na podstawie ustawy. Również na podstawie ustawy mogą być ograniczone prawa i wolności człowieka i obywatela (art. 228 ust. 2 i 3). Tymczasem polski rząd, z powodów nigdy niewyjaśnionych, przejmując, co było naturalne, główną inicjatywę na froncie walki z pandemią, podjął szereg działań nie mieszczących się w kanonie konstytucyjnym. W drodze rozporządzeń zaczęto regulować ważne kwestie dla społeczeństwa nie uwzględniając przy tym, iż niejednokrotnie były one niezgodne $\mathrm{z}$ aktami prawnymi wyższego rzędu oraz naruszały zasady tworzenia prawa. Jak podnosiło wielu ekspertów, działania osób sprawujących władzę w tych trudnych czasach niekiedy nosiły znamiona wadliwej legislacji. L. Morawski, w swoim klasycznym podręczniku, pisał: „W demokratycznych państwach materie szczególnie istotne z punktu widzenia obywateli mogą być uregulowane wyłącznie w ustawie (...)"10. Niżej zostaną

$9 \quad$ Zob. Facebook, blog Mikołaj Małecki, Dogmaty Karnisty

10 L. Morawski, Podstawy prawoznawstwa, wydanie XV, Toruń 2014, s. 100. 
Adam Wąsikowski - Prawa i wolności obywatelskie...

podane przykłady działań prawnych podjętych przez rząd premiera Mateusza Morawieckiego w czasie pandemii, które przez wielu znawców problematyki są postrzegane jako niewiążące, noszące znamiona wadliwej legislacji, a nawet jako naruszające prawa i wolności obywatelskie.

\section{Godzenie w prawa i wolności w czasie epidemii}

Jako pierwszy przykład aktu prawnego polskiego rządu, który ma znamiona wadliwej legislacji, chciałbym przytoczyć rozporządzenie Rady Ministrów ustanawiające nakaz zasłaniania ust i nosa w miejscu publicznym $^{11}$. Dało ono funkcjonariuszom publicznym podstawę do wystawiania mandatów za łamanie tego nakazu. W związku z tym w mediach pojawiały się informacje przedstawiające policjantów zatrzymujących osoby, które nie stosowały się do tego nakazu i stosujących wobec nich środki przymusu bezpośredniego, tj. używanie przemocy fizycznej, zakładanie kajdanek, czy nawet pościg. Oczywiście nie chcąc generalizować, chciałbym zaznaczyć, że każda tego typu sprawa jest indywidualna, jednak niezaprzeczalnym faktem jest to, że niektórzy funkcjonariusze w pewnych przypadkach traktowali obywateli w sposób bardzo represyjny. Nagrania audiowizualne przedstawiające takie zajścia szybko rozprzestrzeniały się wśród Internautów, budząc wątpliwości, czy zachowania niektórych funkcjonariuszy nie godziły w prawa i wolności obywatelskie oraz godność człowieka. Zgodnie z art. 41. ust. 1 Konstytucji RP każdemu zapewnia się nietykalność osobistą i wolność osobistą, zaś jej ograniczenie lub pozbawienie może nastąpić tylko na zasadach i trybie określonym w ustawie. Rzecz jasna istnieją również różnego rodzaju przepisy dookreślające, kiedy funkcjonariusze policji lub innych służb mają prawo kogoś zatrzymać i zazwyczaj przesłanką ku temu jest podejrzenie o popełnienie przestępstwa. Fakt, że ktoś w miejscu publicznym nie miał zasłoniętej twarzy wydaje się być wyjątkowo nikłym powodem, aby dopuszczać się

11 Rozporządzenie Rady Ministrów z dnia 10 kwietnia 2020 r. w sprawie ustanowienia określonych ograniczeń, nakazów i zakazów w związku z występowaniem stanu epidemii, Dz.U. 2020 poz. 1631; zob. § 18 rozporządzenia. 
czynności zmierzających np. do zastosowania w stosunku do takiej osoby środków przymusu bezpośredniego. Warto w tym miejscu także dodać, iż w takich sytuacjach można także pytać o odpowiedzialność przełożonych policjantów. Ci bowiem, stosując drastyczne formy interwencji, wykonywali wszak polecenia i rozkazy. Dotykamy tu zatem problemu taktyki i formy działania pododdziałów interwencyjnych. Trzeba jednocześnie pamiętać, iż większość wspomnianych powyżej sytuacji była wynikiem wprowadzanych przez rząd regulacji prawnych. Wreszcie należy postawić pytanie, czy wprowadzenie nakazu zasłaniania ust i nosa miało ustawową podstawę prawną, a w konsekwencji czy powinno być egzekwowane przez funkcjonariuszy służb mundurowych oraz pracowników Sanepidu. W sytuacji, której ukarany nie godził się z decyzją funkcjonariusza dotyczącą nałożenia mandatu za złamanie tego nakazu, mógł domagać się rozpatrzenia sprawy przez sąd. Nie jest niczym zaskakującym, że sądy uchylały takie mandaty, ponieważ ustawa „O zapobieganiu oraz zwalczaniu zakażeń i chorób zakaźnych u ludzi"12 nie przewidywała takich rozwiązań ochronnych. Przywołane wcześniej rozporządzenie z 10 kwietnia 2020 r. wprowadzające ów nakaz zawierało zatem rozwiązania sprzeczne z regulacjami zawartymi w akcie wyższego rzędu, czyli w ustawie o zapobieganiu oraz zwalczaniu zakażeń i chorób zakaźnych u ludzi z 2008 r. Było to ewidentne naruszenie zasady lex superior derogat legi inferiori, która oznacza: „norma wyższa uchyla normę niższą”. Wątpliwości budzi także kwestia podstawy prawnej kwietniowego rozporządzenia. Analiza treści tego rozporządzenia dowodzi, iż nie było ono wydane na podstawie żadnej ustawy. Art. 92. ust. 1 Konstytucji natomiast rozstrzyga to jednoznacznie. „Rozporządzenia są wydawane przez organy wskazane w Konstytucji, na podstawie szczegółowego upoważnienia zawartego w ustawie i w celu jej wykonania. Upoważnienie powinno określać organ

12 Ustawa z dnia 5 grudnia 2008 r. o zapobieganiu oraz zwalczaniu zakażeń i chorób zakaźnych u ludzi, Dz.U. 2008 nr 234 poz. 1570. Dopiero nowelizacja tej ustawy z dnia 28 października 2020 r. upoważniła Radę Ministrów do ustanowienia „nakazu zakrywania ust i nosa, w określonych okolicznościach, miejscach i obiektach oraz na określonych obszarach, wraz ze sposobem realizacji tego nakazu" (art. 46b pkt 13). Dz.U. 2020, poz.2112,2113, Dz.U 2021, poz.259. 
Adam Wąsikowski - Prawa i wolności obywatelskie...

właściwy do wydania rozporządzenia i zakres spraw przekazanych do uregulowania oraz wytyczne dotyczące treści aktu". Dlatego należy skonstatować, iż rozporządzenie z 10 kwietnia było niezgodne z obowiązującymi zasadami i procedurami tworzenia prawa. Było to zresztą wiele razy podniesione w orzeczeniach sądów.

Kolejne regulacje prawne wprowadzone przez rząd w czasie pandemii COVID-19, które w opinii wielu ekspertów godziły w prawa i wolności obywatelskie, ustanawiały zakaz gromadzenia się powyżej 5. osób w miejscach publicznych. W roku 2020 rządzący wielokrotnie wydawali rozporządzenia regulujące lub nowelizujące wspomnianą kwestię. Należy w tym miejscu wspomnieć, iż zgodnie z rozporządzeniem Rady Ministrów z dn. 21 marca ${ }^{13}$ (zostało ono podtrzymane w rozporządzeniu z 2 maja ${ }^{14}$ ), a także rozporządzeniem z dnia 6 listopada, w przypadku zgromadzeń „maksymalna liczba uczestników nie może być większa niż $5^{\prime \prime 15}$. Nie wdając się w szczegółową analizę treści tych aktów, chciałbym skupić się na tym, czy zawarte w nich regulacje godziły w prawa i wolności obywatelskie. Otóż art. 57. Konstytucji RP stanowi, iż „Każdemu zapewnia się wolność organizowania pokojowych zgromadzeń i uczestniczenia w nich (...)", zaś ograniczenia tej wolności może określać ustawa. Zatem ograniczenie możliwości gromadzenia się obywateli uregulowane przez polski rząd w rozporządzeniach, podobnie jak w przypadku wprowadzenia nakazu zasłaniania ust i nosa, nie było uregulowane w prawidłowy sposób, gdyż było to sprzeczne z Konstytucją. W tym miejscu musi paść pytanie o to, dlaczego rząd nie wprowadził żadnego ze stanów nadzwyczajnych, który by zezwalał na wprowadzanie tego typu nakazów bądź zakazów? Takie działania z całą

13 Rozporządzenie Rady Ministrów z dnia 31 marca 2020 r. w sprawie ustanowienia określonych ograniczeń, nakazów i zakazów w związku z wystąpieniem stanu epidemii, Dz.U. 2020 poz. 566.

14 Rozporządzenie Rady Ministrów z dnia 2 maja 2020 r. w sprawie ustanowienia określonych ograniczeń, nakazów i zakazów w związku z wystąpieniem stanu epidemii, Dz.U. 2020 poz. 792.

15 Rozporządzenie Rady Ministrów z dnia 6 listopada 2020 r. w sprawie ustanowienia określonych ograniczeń, nakazów i zakazów w związku z występowaniem stanu epidemii, Dz.U. 2020 poz. 1758, § 28. 
pewnością określić można jako niezgodne z polskim porządkiem prawnym. I chociaż ocena ta została jednoznacznie sformułowana w orzeczeniach wielu sądów, rząd uporczywie stosuje tę wadliwą działalność prawotwórczą. Ponadto w sprawie wprowadzania zakazu zgromadzeń publicznych wątpliwości miał również Rzecznik Praw Obywatelskich, który w specjalnym komunikacie podnosił, iż takie praktyki prowadzą do naruszenia istoty konstytucyjnego prawa obywateli do zgromadzeń wynikającego z art. 57. Konstytucji ${ }^{16}$.

Innym przykładem działań prawnych rządu polskiego w czasie pandemii COVID-19, które mogły nosić znamiona godzenia w prawa i wolności obywatelskie było rozporządzenie Rady Ministrów z dnia 10 kwietnia wprowadzające czasowy zakaz prowadzenia działalności gospodarczej ${ }^{17}$. W związku z nim większość przedsiębiorstw, lokali, obiektów i innych podmiotów gospodarczych przestało funkcjonować. Przewidując katastrofalne skutki tych decyzji, niektórzy polscy przedsiębiorcy postanowili nie stosować się do decyzji rządzących. Wielu z przedsiębiorców, ale także eksperci wskazywali, iż rozporządzenie to godzi w konstytucyjną wolność prowadzenia działalności gospodarczej (art. 20 i 22 Konstytucji RP). Warto również dodać, że w związku $\mathrm{z}$ wprowadzeniem omawianego zakazu, podejmowane były interwencje i inspekcje, kończące się niejednokrotnie mandatem wystawionym przez funkcjonariusza policji lub pracowników Sanepidu. W tym drugim przypadku odbywało się to $\mathrm{w}$ ramach postępowania administracyjnego. Wymierzane w tym trybie kary były szczególnie dotkliwe. Ocena przyjętych w tym zakresie rozwiązań, formułowana w wielu środowiskach, była jednoznacznie krytyczna. Wybitni prawnicy Polscy podnosili, że rozporządzenie RM z dnia 10 kwietnia jest niekonstytucyjne. Do-

$\overline{16}$ Koronawirus. Adam Bodnar pisze do MSWiA: ograniczenia stopniowo sa znoszone, ale zakaz zgromadzeń pozostaje, https://www.rpo.gov.pl/pl/content/koronawirus-rpo-ograniczenia-stopniowo-znoszone-zakaz-zgromadzen-zostaje, www.rpo. gov.pl, [dostęp: 25.01.2021].

17 Rozporządzenie Rady Ministrów z dnia 10 kwietnia 2020 r. w sprawie ustanowienia określonych ograniczeń, nakazów i zakazów w związku z wystąpieniem stanu epidemii, Dz.U. 2020 poz. 658. 
Adam Wąsikowski - Prawa i wolności obywatelskie...

bitny wyraz takiej oceny znajdujemy w wyroku Wojewódzkiego Sądu Administracyjnego w Opolu, który umorzył postępowanie administracyjne w sprawie fryzjera z Głogówka, na którego Sanepid nałożył grzywnę w wysokości 10 tysięcy złotych za prowadzenie swojej działalności, pomimo zakazu zawartego w rozporządzeniu. W orzeczeniu Sąd ten podkreślił: „(...) wprowadzając ograniczenia wolności i praw człowieka nie można powoływać się na nadzwyczajne okoliczności, uzasadniające szczególne rozwiązania prawne oraz okolicznościami tymi nie można usprawiedliwiać daleko idących ograniczeń swobód obywatelskich wprowadzanych $w$ formie rozporządzeń ${ }^{18}$. Sąd powoływał się m.in. na art. 22. oraz art. 65. ust. 1 Konstytucji RP. Pierwszy z przytoczonych artykułów stanowi, że „Ograniczenie wolności działalności gospodarczej jest dopuszczalne tylko w drodze ustawy i tylko ze względu na ważny interes publiczny”. Zdaniem WSA w Opolu „(...) prawodawca wydał akty prawne rangi rozporządzenia, czyli akty rangi niższej niż ustawa, po to aby ograniczać w czasie epidemii podstawowe wolności i prawa"19. Należy zaznaczyć, iż w chwili sporządzania niniejszego artykułu omawiany wyrok nie jest prawomocny. Jest to ważna okoliczność, gdyż polski system prawa civil law nie przewiduje wyroków precedensowych. Można jednak przypuszczać, że orzeczenia innych sądów w podobnych sprawach powinny być zbliżone. Jak podkreśla wielu ekspertów, stwierdzenie niekonstytucyjności rozporządzenia RM z dn. 19 kwietnia jest dosyć klarowne i nie powinno powodować wątpliwości co do jego zasadności.

\section{Epidemia jako stan nadzwyczajny}

Powyżej zostały zaprezentowane przykłady działań prawnych podejmowanych przez polski rząd w czasie pandemii COVID-19, które budziły i nadal budzą poważne wątpliwości z punktu widzenia posza-

\footnotetext{
$18 \quad$ Wyrok Wojewódzkiego Sądu Administracyjnego w Opolu z dn. 27.10.2020 r., sygn.. akt: II SA/Op 219/20, dostępne w Internecie: http://orzeczenia.nsa.gov.pl/doc/ C73366F87D, dostęp: 25.01.2020].

19 Tamże.
} 
nowania praw i wolności obywatelskich. W tym miejscu warto jednak przyjrzeć się tym działaniom z innej, szerszej perspektywy. Niezaprzeczalnym faktem jest, że działania rządzących w pewnych momentach nosiły znamiona nieważności, niepoprawnej legislacji, godzenia w swobody obywatelskie itp. Jednak rozpatrując tę kwestię w kontekście intencji, jakimi najprawdopodobniej kierowali się rządzący, możemy domniemywać, że starali się oni zahamować rozwój epidemii. L. Morawski $\mathrm{w}$ rozdziale dotyczącym pojmowania i interpretowania prawa m.in. wskazuje na racje funkcjonalne, zgodnie z którymi „Wykładnia prawa nie może także ignorować intencji normodawcy, celów, jakie sobie stawiał, nie może być również obojętna wobec konsekwencji, do jakich prowadzi określone rozumienie przepisu (...) ${ }^{20}$. Jest oczywiste, że gdy mamy do czynienia z realnym zagrożeniem, naczelną dyrektywą działania władz publicznych powinna być troska o życie oraz zdrowie obywateli. Nie oznacza to jednak tego, że powinniśmy akceptować i godzić się na wszystko, co w sposób nieuzasadniony godzi w nasze prawa i wolności, zwłaszcza gdy ograniczenia mogą obiektywnie rzecz ujmując naruszać istotę tych praw i wolności. Zasadna jest krytyka, a nawet sprzeciw obywateli w sytuacji, kiedy rządzący notorycznie, najprawdopodobniej w sposób świadomy i konsekwentny sięgają po rozwiązania prawne niezgodne z zasadami konstytucyjnymi, odwołując się do woluntarystycznej, subiektywnej bądź dyktowanej politycznymi dyrektywami interpretacji, wykładni i zasad stanowienia prawa. Towarzyszy temu praktycznie kompletny brak rzeczowego dialogu ze społeczeństwem i prób uzasadniania poszczególnych decyzji, zwłaszcza regulacji restrykcyjnych. Wydaje się, że można oczywiście uzasadniać potrzebę noszenia maseczek względami medycznymi. Jak bowiem twierdzi większość lekarzy, m.in. prof. W. Gut: „Brak maseczki bardzo zwiększa ryzyko zakażenia koronawirusem $(. . .)^{21}$. Tylko czy należy to koniecznie

\footnotetext{
$20 \quad$ L. Morawski, Podstawy prawoznawstwa, op.cit., s. 137.

21 Prof. Gut w rozmowie z PAP: Brak maseczki znacznie zwiększa ryzyko zakażenia SARS-CoV2-2", www.pap.pl, https://www.pap.pl/aktualnosci/news\%2C751336\%2Cprof-gut-w-rozmowie-z-pap-brak-maseczki-znacznie-zwieksza-ryzyko-zakazenia, [dostęp: 17.03.2021]
} 
Adam Wąsikowski - Prawa i wolności obywatelskie...

formułować $\mathrm{w}$ formie nakazu, rygorystycznie w wielu przypadkach egzekwowanego przez odpowiednie służby? Czy powołując się na ustawę o zwalczaniu chorób zakaźnych, można w drodze rozporządzenia rozszerzać ustalony w niej katalog warunków, jakie muszą zaistnieć, by można było ustanowić taki nakaz? Nawet wówczas, gdy noszenie maseczek korzystnie wpływa na nasze zdrowie i dobro ogółu? Podobne pytania mogą rodzić się w odniesieniu do restrykcji dotyczących zgromadzeń publicznych, które były oceniane przez wielu ekspertów, a także RPO, Adama Bodnara, jako godzące w prawa i wolności obywatelskie. Czy w takiej sytuacji powinniśmy ostentacyjnie nie przestrzegać takich zakazów i ograniczyć się do uzasadnionego skądinąd podnoszenia, że łamane są nasze konstytucyjne prawa dotyczące zgromadzeń? Czy uzasadnione jest stosowanie w różnych formach obywatelskiego nieposłuszeństwa i oporu? Wydaje się, że każdy z nas powinien w takich przypadkach kierować się tzw. zdrowym rozsądkiem, a także we własnym zakresie dążyć do ochrony swojego zdrowia i innych osób. Ale i władze publiczne, w demokratycznym państwie nie powinny działać, kierując się wyłącznie schematem: zakaz - przymus/represja - kara.

Z najbardziej chyba skomplikowaną sytuacją mamy do czynienia w przypadku decyzji czasowo zakazujących prowadzenia działalności gospodarczej. Wątpliwości potęguje zwłaszcza fakt, że jak np. orzekł WSA w Opolu, wspomniane wcześniej rozporządzenie Rady Ministrów nie powinno obowiązywać, ponieważ władze nie zdecydowały się na wprowadzenie stanu wyjątkowego albo stanu klęski żywiołowej, co pozwoliłoby legalnie, z zachowaniem zasad konstytucyjnych, zabraniać prowadzenia działalności gospodarczej. Nieprawomocny jeszcze, co wyżej podkreślano, wyrok WSA w Opolu jednoznacznie nakreślił, że działania rządzących w tym zakresie są nieważne i nie dają podstawy do karania obywateli za prowadzenie działalności gospodarczej zgodnie z panującymi wymogami i reżimem sanitarnym. Tutaj znowu należałoby odwołać się do tzw. zdrowego rozsądku obywateli i zasad współżycia społecznego. W tym kontekście warto przypomnieć, że to obowiązkiem tworzących prawo jest uwzględnianie różnych czynników, popraw- 
ne komunikowanie się ze społeczeństwem i działanie na rzecz dobra ogółu. Niestety przykład rozporządzenia RM z dnia 10 kwietnia 2020 r. obrazuje, że oprócz tego, iż prawodawca nie zastosował się do zasad tworzenia prawa, ograniczył konstytucyjne prawa prowadzenia działalności gospodarczej, to $w$ dodatku nie potrafił wytłumaczyć swojej decyzji. Nie przedstawiono również żadnych racjonalnych argumentów uzasadniających ocenę, że np. osoby przebywające w restauracjach lub na stokach narciarskich, jednocześnie stosujące się do wymogów reżimu sanitarnego i reguły dystansu społecznego, są bardziej narażone na zakażenie wirusem niż dajmy na to w sklepach wielkopowierzchniowych, których działalności nie zakazano. Jest oczywiste, że każdy rozsądny człowiek powinien dokonać kalkulacji czy jednak nie należy prawidłowo nosić maseczki ograniczającej rozprzestrzenianie się wirusa, choć nakazujący to akt prawny jest sprzeczny z konstytucyjnymi zasadami stanowienia prawa. Ograniczenie bądź zakaz prowadzenia działalności gospodarczej wywołały oburzenie i sprzeciw przedsiębiorców. Władze i w tym przypadku nie przedstawiły przekonujących uzasadnień, opartych na przykład na wynikach szczegółowych badań na temat zagrożenia epidemiologicznego w konkretnych podmiotach gospodarczych. Decyzje rządu były dla większości przedsiębiorców niezrozumiałe. Autorzy rozporządzenia nie zmierzyli się z racjami przedsiębiorców, ignorując sformułowane w preambule Konstytucji RP zasady dialogu społecznego i pomocniczości. W działalności prawotwórczej należy ciągle pamiętać, iż ustanowione wbrew przyjętym zasadom prawo jest złem, jednak o wiele gorsze jest prawo niezrozumiałe. Stanowienie prawa jest niezwykle odpowiedzialną funkcją organów władzy publicznej. Normy prawne są wzorami powinnych zachowań ich adresatów i nie mogą być tworzone bez gruntownej znajomości badanej materii. Możliwe błędy należy eliminować natychmiast. Tym bardziej niedopuszczalne jest utrwalanie/kontynuowanie wadliwej legislacji i uzasadnianie tej praktyki przy pomocy błędnej argumentacji bądź zerwanie jakichkolwiek form dialogu społecznego w tym zakresie. Taka praktyka może powodować utratę szacunku wobec prawa oraz podważać zasadę jego 
Adam Wąsikowski - Prawa i wolności obywatelskie...

pewności/trwałości, co w konsekwencji prowadzić może do chaosu ${ }^{22}$, a w skrajnych przypadkach nawet rodzić postawy anarchistyczne. Nie służy to również budowaniu, tak potrzebnego w trudnej sytuacji, autorytetu władzy publicznej. Jak pisał L. Morawski: „(...) wykładnia prawa nie może się ograniczać do kontekstu językowego i systemowego danego przepisu, ale musi brać pod uwagę szeroko rozumiany kontekst funkcjonalny, a więc czynniki społeczne, ekonomiczne, polityczne i moralne"23.

W społecznej dyskusji, publicystyce i opiniach specjalistów, głównym błędem rządzących było i pozostaje zaniechanie wprowadzenia jednego ze stanów nadzwyczajnych, na co zezwala art. 228. ust. 1 Konstytucji RP. Najczęściej wskazuje się, że już w fazie zagrożenia epidemicznego było uzasadnione wprowadzenie stanu klęski żywiołowej. Pozwala na to, $\mathrm{z}$ formalnego punktu widzenia, ustawa z 18 kwietnia $2002 \mathrm{r}^{24}$ o stanie klęski żywiołowej. W myśl art. 3. tej ustawy jedną z przesłanek ogłoszenia stanu klęski żywiołowej jest występowanie chorób zakaźnych wśród ludzi. Takie rozwiązanie stworzyłoby podstawy legalności wielu kolejnych, niezbędnych decyzji prawnych. Bezpodstawne byłoby wówczas podnoszenie zarzutów dotyczących bezprawnego naruszania praw i godzenia w swobody obywatelskie. Jest bowiem dopuszczalne, w pewnych wyjątkowych okolicznościach, tymczasowe ograniczenie swobód obywatelskich. Jednak rząd premiera Mateusza Morawieckiego, z nieznanych opinii publicznej powodów, nie zdecydował się na takie rozwiązanie. Niektórzy komentatorzy twierdzą, iż stanowisko to mogło być podyktowane obawami przed koniecznością późniejszego wypłacania przez państwo odszkodowań podmiotom, które poniosły straty w związku z wprowadzeniem stanu nadzwyczajnego. Reguluje to

\footnotetext{
22 Potwierdza to zamieszanie powstałe po ogłoszeniu Rozporządzenia Rady Ministrów z dnia 21 grudnia 2020 r. $w$ sprawie ustanowienia określonych ograniczeń, nakazów i zakazów w zwiq̨zku z wystąieniem stanu epidemii. Dz. U. 2020, poz.2316. Na tej podstawie wprowadzono tzw. „sylwestrowo-noworoczną godzinę policyjną”, która miała obowiązywać w czasie: 31 grudnia 2020 r., g. 19 - 1 stycznia 2021 r., g.6).

23 L. Morawski, Podstawy prawoznawstwa, op.cit., s. 137.

24 Dz.U. $2009 \mathrm{nr} 62$ poz. 558.
} 
ustawa z dnia 22 listopada 2002 r. o wyrównywaniu strat majątkowych wynikających z ograniczenia w czasie stanu nadzwyczajnego wolności i praw człowieka i obywatela ${ }^{25}$. Zgodnie z art. 2. ust. 1. tej ustawy „Każdemu, kto poniósł stratę majątkową w następstwie ograniczenia wolności i praw człowieka i obywatela w czasie stanu nadzwyczajnego, służy roszczenie o odszkodowanie". Oczywiście osoby fizyczne prowadzące działalność gospodarczą oraz instytucjonalne podmioty gospodarcze, także w warunkach aktualnych regulacji prawnych, mają prawo domagać się na drodze sądowej odszkodowań za straty poniesione w związku $\mathrm{z}$ „zamknięciem gospodarki” w czasie pandemii. Jednakże nie wiadomo, czy i w jakim zakresie sądy w takiej sytuacji będą uznawały te roszczenia. Pandemia jest nieoczekiwanym i nowym zjawiskiem, co w naturalny sposób wywołuje dyskusję dotyczącą konieczności ustanawiania adekwatnych regulacji prawnych. Niezbędne jest niewątpliwie podjęcie odpowiednich prac w tym zakresie przez rząd i inne właściwe organy państwa. Manifestowana dotąd przez nie uznaniowość i sprzeczne $\mathrm{z}$ zasadami ustrojowymi decyzje oraz ich uzasadnianie nie budują autorytetu władzy ani szacunku dla prawa. Niedopuszczalna jest również labilna interpretacja i niekonsekwentna praktyka wdrażania w życie niektórych obostrzeń, jak to miało miejsce w przypadku wprowadzenia godziny policyjnej na noc sylwestrową, o czym była mowa wyżej.

\section{Podsumowanie}

Nadzwyczajna sytuacja, jaką bez wątpienie jest pandemia COVID-19 i stosowane w związku z nią regulacje prawne, nadały dyskusji o prawach i wolnościach obywatelskich nowy wymiar oraz wywołały wysoki poziom społecznych emocji. Odsłoniły one również szereg deficytów aparatu państwowego dotyczących jego sprawności, zdolności do szybkiego, adekwatnego reagowania na pojawiające się problemy oraz profesjonalizmu osób i zespołów odpowiedzialnych za organizowanie i kierowanie życiem społecznym na poszczególnych odcinkach. Zasady, tryb i proce-

$25 \quad$ Dz.U. 2002 nr 233 poz. 1955. 
Adam Wąsikowski - Prawa i wolności obywatelskie...

dury podejmowania $w$ tych warunkach decyzji ujawniły również rzeczywistą „filozofię" rozumienia władzy i roli prawa oraz stosunek „ludzi władzy" do fundamentalnych zasad demokratycznego państwa prawa. Ignorowanie głosów uzasadnionej krytyki naruszania reguł poprawnej legislacji, relatywizujące interpretacje zasad ustrojowych oraz interesu publicznego i stosowanie rozmaitych chwytów erystycznych w komunikacji ze społeczeństwem służą realizacji interesów politycznych sił dziś sprawujących władzę. Dążenie do przeprowadzenia w maju 2020 r. wyborów prezydenckich przesłaniało realne niebezpieczeństwo dla zdrowia mieszkańców Polski ${ }^{26}$. Konieczne i uzasadnione decyzje dotyczące pomocy polskim przedsiębiorcom mogły od początku być podejmowane w oparciu o ustawę z dnia 22 listopada 2002 r. o wyrównywaniu strat majątkowych wynikających z ograniczenia w czasie stanu nadzwyczajnego wolności i praw człowieka i obywatela. Można było uniknąć pewnego chaosu i wątpliwości w sferze stanowienia prawa oraz zapewnić przejrzystość i legalność przyjmowanych rozwiązań. Zachowanie porządku konstytucyjnego dawałoby również formalne podstawy niezbędnych ograniczeń wolności i praw człowieka i obywatela. W takim przypadku łatwiej uzyskać zrozumienie i aprobatę społeczeństwa dla decyzji władz publicznych, choć niosą one niekiedy uciążliwe restrykcje.

\section{Literatura}

Chmaj M., Wolności i prawa człowieka w Konstytucji Rzeczypospolitej Polskiej, Warszawa 2008.

Garlicki L., Polskie prawo konstytucyjne. Zarys wykładu. Warszawa 2019.

Michalska A., Prawa człowieka w systemie norm międzynarodowych, Warszawa-Poznań 1982.

Morawski L., Podstawy prawoznawstwa, wydanie XV, Toruń 2014.

Stecko S., Prawa i wolności człowieka i obywatela $w$ świetle Konstytucji RP, „Przegląd Prawa Konstytucyjnego” 2018, nr 1 (41).

$26 \quad$ Ustawa z dnia 2 czerwca 2020 r. o szczególnych zasadach organizacji wyborów powszechnych Prezydenta Rzeczypospolitej Polskiej z możliwościq głosowania korespondencyjnego. Dz. U. 2020 r., poz.979. 
Szczaniecki M., Sójka-Zielińska K., Powszechna historia państwa i prawa, Warszawa 2009.

\section{Źródła prawne}

Konstytucja Rzeczypospolitej Polskiej z dnia 2 kwietnia 1997 r., Dz.U. 1997, nr 78, poz. 483. ze zm.

Ustawa z dn. 18 kwietnia 2002 r. o stanie klęski żywiołowej, Dz.U. 2009 nr 62 poz. 558.

Ustawa z dn. 22 listopada 2002 r. o wyrównywaniu strat majątkowych wynikających z ograniczenia w czasie stanu nadzwyczajnego wolności i praw człowieka i obywatela, Dz.U. 2002 nr 233 poz. 1955,

Ustawa z dnia 5 grudnia 2008 r. o zapobieganiu oraz zwalczaniu zakażeń i chorób zakaźnych u ludzi, Dz.U. 2008 nr 234 poz. 1570.

Ustawa z dnia 2 marca 2020 r. o szczególnych rozwiązaniach związanych z zapobieganiem, przeciwdziałaniem i zwalczaniem COVID-19, innych chorób zakaźnych oraz wywołanych nimi sytuacji kryzysowych, Dz.U. 2020 poz. 374.

Rozporządzenie Ministra Zdrowia z dnia 13 marca 2020 r. w sprawie ogłoszenia na obszarze Rzeczypospolitej Polskiej stanu zagrożenia epidemicznego, Dz.U. 2020 poz. 433.

Rozporządzenie Ministra Zdrowia z dnia 20 marca 2020 r. w sprawie ogłoszenia na obszarze Rzeczypospolitej Polskiej stanu epidemii, Dz.U. 2020 poz. 491.

Rozporządzenie Rady Ministrów z dnia 31 marca 2020 r. w sprawie ustanowienia określonych ograniczeń, nakazów i zakazów w związku z wystąpieniem stanu epidemii, Dz.U. 2020 poz. 566.

Rozporządzenie Rady Ministrów z dnia 10 kwietnia 2020 r. w sprawie ustanowienia określonych ograniczeń, nakazów i zakazów w związku z występowaniem stanu epidemii, Dz.U. 2020 poz. 658.

Rozporządzenie Rady Ministrów z dnia 19 kwietnia 2020 r. w sprawie ustanowienia określonych ograniczeń, nakazów i zakazów w związku z wystąpieniem stanu epidemii, Dz.U. 2020 poz. 697.

Rozporządzenie Rady Ministrów z dnia 2 maja 2020 r. w sprawie ustanowienia określonych ograniczeń, nakazów i zakazów w związku z wystąpieniem stanu epidemii, Dz.U. 2020 poz. 792. 
Adam Wąsikowski - Prawa i wolności obywatelskie...

Rozporządzenie Rady Ministrów z dnia 6 listopada 2020 r. w sprawie ustanowienia określonych ograniczeń, nakazów i zakazów w związku z występowaniem stanu epidemii, Dz.U. 2020 poz. 1758,

Wyrok Wojewódzkiego Sądu Administracyjnego w Opolu z dn. 27.10.2020 r., sygn.. akt: II SA/Op 219/20.

\section{Netografia}

Koronawirus. Adam Bodnar pisze do MSWiA: ograniczenia stopniowo sq znoszone, ale zakaz zgromadzeń pozostaje, https://www.rpo.gov.pl/pl/content/ koronawirus-rpo-ograniczenia-stopniowo-znoszone-zakaz-zgromadzen-zostaje, www.rpo.gov.pl, [dostęp: 25.01.2021].

Prof. Gut w rozmowie z PAP: Brak maseczki znacznie zwiększa ryzyko zakażenia SARS-CoV2-2", www.pap.pl, https://www.pap.pl/aktualnosci/news\%2C751336\%2Cprof-gut-w-rozmowie-z-pap-brak-maseczki-znacznie-zwieksza-ryzyko-zakazenia, [dostęp: 17.03.2021]. 